\section{UDC:35}

DOI: https://doi.org/10.32689/26172224-2019-4(19)-312-319

\section{Жукова Ірина Віталіївна,}

кандидат наук з державного управління, дочент, виконавчий директор Президіі Всеукраїнської асамблеї докторів наук з державного управління, завідувач кафедри професійної освіти та управління навчальним закладом, Міжрегіональна Академія управління персоналом, 03039, м. Київ, вул. Фрометівська, 2, тел.: +38 (063) 9517855 ,e-mail:irina pravo@ukr.net

ORCID: 00000-0003-4927-0610

\section{Жукова Ирина Витальевна,}

кандидат наук по государственному управлению, доцент, исполнительный директор Президиума Всеукраинской ассамблеи докторов наук по государственному управлению, заведующий кафедрой профессионального образования $и$ управления учебным заведением, Межрегиональная Академия управления персоналом, 03039, г. Киев, ул. Фрометовская, 2, тел.: +38 (063) 95178 55, e-mail: irina_ pravo@ukr.net

ORCID: 0000-0003-4927-0610

\section{Zhukova Iryna Vitaliivna,}

PhD in Public Administration, assistant professor, Executive Director of the Presidium of the civic scientific organization, "Ukrainian Assembly of doctors of science in public administration", Head of the Department of Vocational Education and School Management, Interregional Academy of Personnel Management, 03039, Kyiv, Str. Frometivska, 2, tel.: +38 (063) 95178 55, e-mail:irina_pravo@ukr.net

ORCID: 0000-0003-4927-0610

\section{Долгий Олександр Андрійович,}

доктор наук із державного управління, професор, т.в.о. провідного наукового співробітника відділу публічного управління иивільним захистом науково-дослідного иентру заходів цивільного захисту, Украйнський науково-дослідний інститут иивільного захисту, 01011, м. Київ, вул. Рибальська, 18, +38 (063)9517855, e-mail:dolgiy_2019@ukr.net

ORCID: 0000-0003-4433-454X
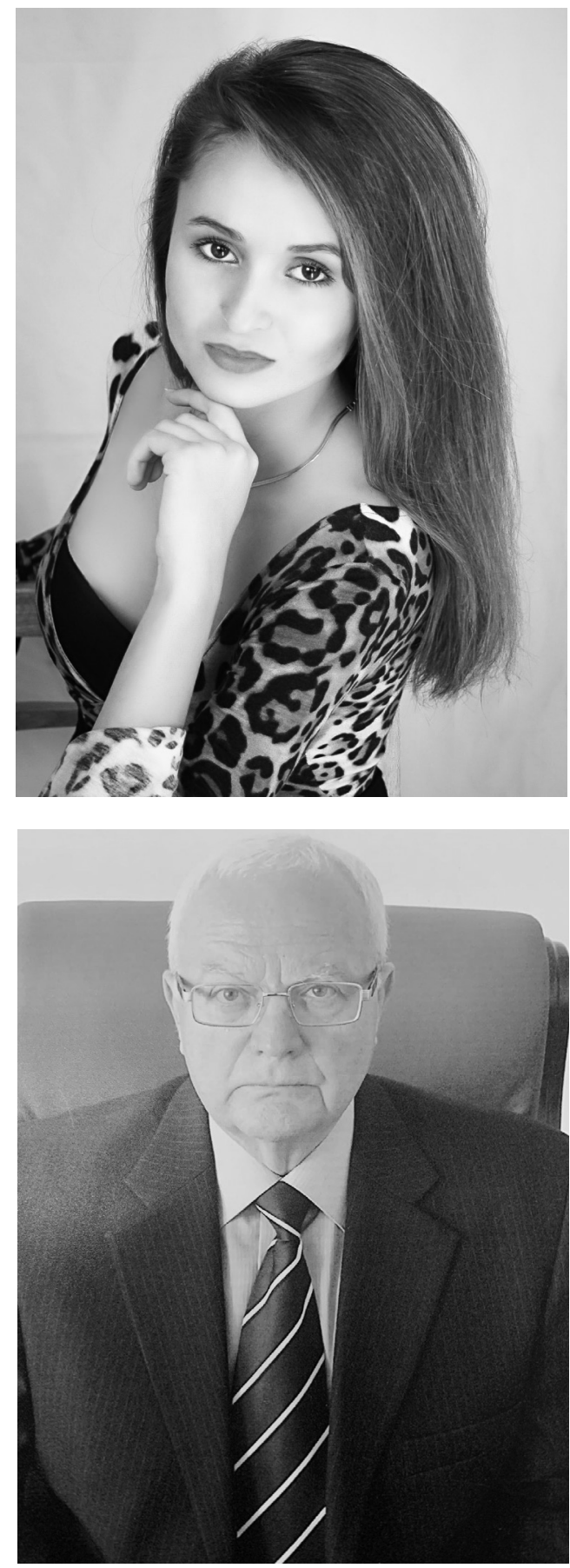
Долгий Александр Андреевич,

доктор наук по государственному управлению, профессор, в.и.о. ведущего научного сотрудника отдела публиного управления гражданской защитой научно-исследовательского иентра мероприятий гражданской защиты, Украинский научно-исследовательский институт гражданской защиты, 01011, г. Киев, ул. Рыбальская, 18, +38 (063) 95178 55, e-mail:dolgiy_2019@ ukr.net

ORCID: 0000-0003-4433-454X

\section{Dolgiy Oleksandr Andriyozych,}

Doctor of Science in Public Administration, Professor, temporarily acting of the Leading Researcher at the Department of Public Administration for Civil Protection of the research center of Civil Protection Measures, Ukrainian Civil Defense Research Institute, 01011, Kyiv, Rybalskaya Str., 18, +38 (063) 951 7855, e-mail:dolgiy_2019@ ukr.net

ORCID: 0000-0003-4433-454X

\section{ТЕОРЕТИКО-МЕТОДОЛОГІЧНА ТА СОЦІАЛЬНО-ПРАКТИЧНА АКТУАЛІЗАЦІЯ РОЛІ КОМУНІКАЦІї}

Анотація. Встановлено, що значення феномену комунікацій на сучасному етапі розвитку суспільства важко недооцінити, адже комунікаційні зв'язки пронизують усі сфери життєдіяльності, комунікації досліджуються різними науками: державним управлінням, економікою, правом, соціологією, філософією, культурологією, політологією тощо.

Досліджуючи комунікації крізь призму взаємодії державних органів влади та громадськості на регіональному рівні, більшість дослідників тлумачать комунікацію як основу державного управління і важливий чинник демократизації суспільного життя. В загальному вигляді її можна визначити як процес обміну інформацією, що об'єднує в єдине ціле органи державного управління, органи місцевого самоврядування та групи громадськості; зміцнює необхідний зворотний зв'язок між адміністративним апаратом, управлінськими структурами, суспільством, окремими громадами й індивідами.

Як процес передачі, обміну політичною інформацією, який структурує політичну діяльність і надає їй нового значення, формує громадську думку і політичну соціалізацію громадян з урахуванням їх потреб та інтересів тлумачиться поняття “комунікація політична”.

Обгрунтовано, що комунікації в державному управлінні розглядають як інформаційну взаємодію, орієнтовану безпосередньо на визначену організацію, на методи і засоби побудови внутрішніх взаємозв'язків, тобто як інформаційні потоки; на розуміння побудови відносин між людьми всередині організації і в непомітному перенесенні особистих відносин на організаційні, у поєднанні вражень, заснованих на почутті симпатії або антипатії, і вражень від ділових 
якостей, а “комунікацію управлінську як сукупність інформаційних зв’язків, процес взаємодії між суб’єктами управлінської діяльності по вертикалі, горизонталі із зовнішнім суспільним середовищем, шляхом безпосереднього спілкування і обміну інформацією з використанням відповідних засобів”.

Ключові слова: комунікація державного управління, демократизація суспільного життя, комунікація управлінська, комунікативне середовище.

\section{ТЕОРЕТИКО-МЕТОДОЛОГИЧЕСКАЯ И СОЦИАЛЬНО-ПРАКТИЧЕСКАЯ АКТУАЛИЗАЦИЯ РОЛИ КОММУНИКАЦИИ}

Аннотация. Установлено, что значение феномена коммуникаций на современном этапе развития общества трудно недооценить, ведь коммуникационные связи пронизывают все сферы жизнедеятельности, коммуникации исследуются различными науками: государственным управлением, экономикой, правом, социологией, философией, культурологией, политологией и др.

Исследуя коммуникации через призму взаимодействия государственных органов власти и общественности на региональном уровне большинство исследователей объясняют коммуникацию как основу государственного управления и важный фактор демократизации общественной жизни. В общем виде ее можно определить как процесс обмена информацией, который объединяет в единое целое органы государственного управления, органы местного самоуправления и группы общественности; укрепляет необходимую обратную связь между административным аппаратом, управленческими структурами, обществом, отдельными общинами и индивидами.

Как процесс передачи, обмена политической информацией, который структурирует политическую деятельность и придает ей новое значение, формирует общественное мнение и политическую социализацию граждан с учетом их потребностей и интересов толкуется понятие “коммуникация политическая".

Обосновано, что коммуникации в государственном управлении рассматривают как информационное взаимодействие, ориентированное непосредственно на определенную организацию, на методы и средства построения внутренних взаимосвязей, то есть как информационные потоки; на понимание построения отношений между людьми внутри организации и в незаметном переносе личных отношений на организационные, в сочетании впечатлений, основанных на чувстве симпатии или антипатии, и впечатлений от деловых качеств, а “коммуникацию управленческую как совокупность информационных связей, процесс взаимодействия между субъектами управленческой деятельности по вертикали, горизонтали с внешней общественной средой, путем непосредственного общения и обмена информацией с использованием соответствующих средств"”.

Ключевые слова: коммуникация государственного управления, демократизация общественной жизни, коммуникация управленческая, коммуникативная среда. 


\title{
THEORETICAL-METHODOLOGICAL AND SOCIO-PRACTICAL ACTUALIZATION \\ OF THE COMMUNICATION ROLE
}

\begin{abstract}
It is determined that the value of the phenomenon of communication at the present stage of development of society can barely be underestimated, because communication links permeate all spheres of life, communication is studied by different sciences: public administration, economics, law, sociology, philosophy, cultural studies, political science, and the like.

While exploring communication through the prism of interaction between public authorities and the public at the regional level, most researchers interpret communication as the basis of public administration and an important factor in the democratization of public life. Generally, it can be defined as the process of information exchange, which brings together the bodies of state administration, local governments and public groups; strengthens the need for feedback between the administrative apparatus, management structures, society, individual communities and individuals.

The concept of "political communication" is interpreted as a process of transmission, exchange of political information, which structures political activity and gives it a new meaning, forms public opinion and political socialization of citizens, taking into account their needs and interests.

It is proved that communication in public administration is considered as information interaction, focused directly on a particular organization, methods and means of building internal relationships, that is, as information flows; on the understanding of building relationships between people within the organization and in the imperceptible transfer of personal relationships to organizational, combined impressions based on a sense of sympathy or antipathy, and impressions of business qualities, as well as "management communication as a set of information links, the process of interaction between the subjects of management activities vertically, horizontally with the external social environment, through direct communication and exchange of information using appropriate means".
\end{abstract}

Keywords: communication of public administration, democratization of public life, communication management, communicative environment.

Постановка проблеми. У реаліях сьогодення на етапі соціально-економічного та політичного розвитку роль комунікації набуває величезної теоретико-методологічної та соціально-практичної актуалізації, зумовленої їі повним проникненням у всі сфери суспільного життя. Це призвело до затвердження нових комунікативних структур, процесів i форм, які забезпечили якісну зміну соціального та комунікативного середовища нашого світу. Значущість і необхідність ретельного наукового дослідження ролі комунікації полягає в тому, що використання різних 
форм і методів спілкування, вільний доступ громадян до інформації на всіх етапах прийняття рішень i функціонування центральних і місцевих органів влади, участь Інституту громадянського суспільства в роботі експертних, консультаційних та дорадчих громадських рад з питань висвітлення та захисту прав і свобод громадян, громадського контролю, прямого електронного отримання державних послуг тощо є важливими факторами демократизації державного управління. Насамперед мова йде про свідому орієнтацію на нове сприйняття цінностей, а саме індивіда та групи людей (колективу), їх безпосередню участь у демократичній організації життя держави і суспільства. Головне в цьому контексті полягає в тому, що раціональний консенсус громадянського суспільства і держави є фактором загального суспільного дискурсу i стратегічним ресурсом демократичного розвитку. Таким чином, комунікація у світлі демократизації державного управління має особливе значення як для органів державної влади, так і для інститутів громадянського суспільства в Україні [1, c. 6,8$]$.

Аналіз останніх досліджень і публікацій. Варто зазначити, що поряд 3 категорією “комунікація”, експерти часто порівнюють поняття “інформація”, дослідники М. Мескон, М. Альберт, Ф. Хедаури вважають категорію “комунікація” обміном інформацією на основі якої керівництво отримує інформацію, необхідну для прийняття ефективних рішень i приймає рішення щодо працівників організації (компанії) [2, с. 19].
Мета статті - дослідити теоретико-методологічну та соціально-практичну актуалізацію ролі комунікації.

Виклад основного матеріалу дослідження. Поняття комунікація постійно трансформується та поповнюється новими характеристиками та суттєвими ознаками, саме тому узагальнення за аналогією таких понять як, наприклад, політика, інформація тощо в принципі неможлива. Досить аргументовані докази з цього питання за аналогією з поняттям “масові комунікації розглянула ще у 1999 р. О. Зернецька [3; 4, с. 18-19]. Більш чітке розмежування понять “комунікація” і “комунікаці1” знаходимо також у статті Д. Кіслова “Термінологія комунікацій: теоретичний дискурс та його практичне використання”. В ній зазначається: "Комунікація - це природно-соціальний феномен, явище глобально-космічного виміру, що є загальним відображенням симбіозу складних, багаторівневих процесів пересування будь-чого та будь-кого у часі й просторі, у тому числі, кодів і символів штучно-природного походження всіх форм буття, які містять в собі інформацію.

Комунікації - це природно-штучна сукупність конкретних систем, що своїми специфічними засобами реалізує всі відомі функції: переміщення, пересування, транспортування матеріальних об'єктів; передача інформаційних потоків; здійснення спілкування людей і живих організмів; зв'язок в локальному, планетарному і космічному вимірах"[5, с. 49].

Звичайно, як стверджує Д. Кіслов, визначення описаних понять може бути лише відносним і залежить від часу, предметної сфери, глибини на- 
укового осмислення, рівня цивілізаційного розвитку та багатьох інших факторів. В цілому ж, на нашу думку, запропонований підхід до визначення понять “комунікація” i “комунікації” можна розглядати в контексті видового та родового аспектів. Складовими загальної системи комунікацій виступають галузеві, цільові, спеціальні, технологічні та інші види комунікацій в різних сферах людської життєдіяльності, у тому числі: політичній, соціальній, управлінській, науковій, маркетинговій тощо та їх комбінації й різновиди [6, с. 46].

Порівнюючи визначення понять “комунікація" багатьма зарубіжними авторами, Т. Науменко робить узагальнення, що вони можуть бути об'єднані за трьома ознаками: "по-перше, комунікація розглядається як зв’язок між різними об'єктами. Такі некатегоричні визначення характерні в основному для повсякденного розуміння комунікації. По-друге, комунікація розуміється як аналог спілкування. По-третє, комунікація розуміється як аналог впливу" [7, с. 42].

Дане порівняння свідчить, що перші два підходи передбачають комунікацію у вигляді двостороннього зв’язку. Така інтерпретація зв'язку грунтується на уявленні, що зв'язок між різними об'єктами, або як аналог зв'язку між суб'єктами, може відбуватися як двосторонній процес обміну повідомленнями (сигналами), який обумовлений змістом взаємозв’язку між комунікаторами i соціальним середовищем. Тобто, мова йде про те, що у процесі двостороннього зв’язку “і той, хто посилає, і той, хто отримує інформацію, діють в межах своїх взаємин, що склалися між ними і соціальною ситуацією, що оточує $\ddot{1 x} ”[8$, с. 20].

3 огляду на зазначене, можемо констатувати, що комунікація $є$ процесом передачі інформації між суб'єктами соціальної сфери суспільства. Взагалі термін “комунікація” використовується багатьма соціальними, біологічними, технічними науками. Але у будь-якому випадку комунікація передбачає наявність як мінімум трьох учасників цього процесу: передавач - повідомлення - приймач. Таким чином вимальовується, що комунікація $є$ різновидом взаємодії між певними суб'єктами (передавач, приймач) за посередництвом певного об'єкта (повідомлення).

Перегляд наукових розробок зарубіжних i вітчизняних учених показує, що, незважаючи на те, що поняття “комунікація" є предметом дослідження й використання досить широкого кола природничих i гуманітарних наук, питання про функціональні особливості комунікації та демократичного ресурсу системного впливу на ефективну взаємодію органів державної влади й громадськості ще не знайшли свого комплексного вирішення в науці державного управління. Крім того, проблема впливу громадянської комунікації на становлення та розвиток демократичного державного управління в Україні відповідно до європейських демократичних стандартів ще не стала особливим об'єктом наукових досліджень [9, с. 22]

Енциклопедичний словник 3 державного управління за ред. Ю. Ковбасюка, В. Трощинського, Ю. Сурміна, приділяе значну увагу 
комунікативній проблематиці, розглядаючи дефініції “комунікації, “комунікації організаційні”, “комунікація управлінська”, “комунікація в державному управлінні” та тлумачить “комунікації як передачу i прийом інформації, наказів, емоцій, джерело життєвої сили будь-якої організації, оскільки одна 3 найважливіших цілей комунікації полягає в тому, щоб здійснювати субординацію та координацію різноманітних елементів організації” [10, с. 330].

Досліджуючи сутність та функції комунікації в системі державного управління С. В. Драчов, наголошує, що “при здійсненні основних управлінських функцій - планування, організації, мотиваціі, координації, аналізу та контролю, - комунікація виступає як інтегруючий фактор: використовуючи потоки інформації, вона спрямовує повідомлення від однієї ланки до іншої відповідно до встановлених цілей. Фактично, система обробки інформації виступає об’єднуючою функцією для всіх підсистем, або підрозділів державного управління".

Розмежовуючи поняття “державно-управлінська комунікація” (налагодження інформаційно-комунікативних процесів у сфері державного управління) та “державно-урядова комунікація” (як їі структурна складова, яка забезпечує безпосереднє комунікування між урядом, бізнесом та громадськістю) Є. О. Романенком було виокремлено ㄲi комунікативні рівні: внутрішній, що стосується структурної взаємодії органів державної влади і їх взаємодії з громадськістю, та зовнішній, який стосується взаємодії держави та 111 ін- ституційних структур у напрямі реалізації зовнішньої політики.

Наголошуючи на тому, що процес комунікації може відбуватися незалежно від часових бар'єрів і технологічних особливостей поширення інформації, О. Радченко, Г. Головченко вважають, що “обмін інформацією між автором книги і читачем може здійснюватись через сторіччя. В цьому випадку книга є носієм (каналом) інформації, а здійснення соціальної комунікації між іншими членами суспільства забезпечує iï поширення на невизначену аудиторію і i трансформацію у масову”.

\section{СПИСОК ВИКОРИСТАНИХ ДЖЕРЕЛ}

1. Державно-громадянська комунікація: шлях від кризи до взаємодії: монографія / [В. М. Козаков, О. В. Рашковська, В. А. Ребкало, Є. О. Романенко, І. В. Чаплай]. К.: ДП “ВД “Персонал”, 2017. 288 с.

2. Бухтатий О. Україна медійна: на порозі інформаційної революції / О. Бухтатий, О. Радченко, Г. Головченко. К.: Видавець СВС Панасенко, 2015. 208 c.

3. Красин Ю. А. Судьбы демократии в России // Демократия, управление, культура: проблемное измерение современной политики. Ежегодник. Полит. наука / Ю. А. Красин. М.: PОССПЕН, 2007. С. 40-60.

4. Рашковська О. В. Громадянські ініціативи в розвитку комунікацій між державою та суспільством в Україні / О. В. Рашковська // Зб. наук. пр. НАДУ. № 2. 2012. 285 с.

5. Енциклопедичний словник 3 державного управління: / уклад.: Ю. П. Сурмін, В. Д. Бакуменко, А. Михненко та ін.; за ред. Ю. В. Ков- 
басюка, В. П. Трощинського, Ю. П. Сурміна. К.: НАДУ, 2010. $820 \mathrm{c}$.

6. Мазур В. Г. Комунікації як механізм взаємодії державних органів влади та громадськості на регіональному рівні / В. Г. Мазур // Державне управління: удосконалення та розвиток. 2011. № 8.

7. Політологічний енциклопедичний словник / упоряд. В. П. Горбатенко; за ред. Ю. С. Шемшученка, В. Д. Бабкіна, В. П. Горбатенка. 2-ге вид., допов. і переробл. К.: Генеза, 2004. $736 \mathrm{c}$.

8. Енциклопедичний словник 3 державного управління: / уклад.: Ю. П. Сурмін, В. Д. Бакуменко, А. Михненко та ін.; за ред. Ю. В. Ковбасюка, В. П. Трощинського, Ю. П. Сурміна. К.: НАДУ, 2010. $820 \mathrm{c}$.

9. Драчов Є. В. Сутність та функції комунікації в системі державного управління / Є. В. Драчов // Наук. вісн. Академії муніципального управління / Є. В. Драчов, 2014. (Управління; 3). С. 159-167.

10. Романенко $Є$. О. Комунікативна політика держави: теоретико-методологічний аналіз : [монографія] / Є. О. Романенко ; Нац. акад. держ. упр. при Президентові України. К. : НАДУ, 2014. 399 с.

\section{REFERENCES}

1. Kozakov V. M., Rashkovskaya O. V., Rebkalo V. A., Romanenko E. O., Chaplay I. V. (2017). Derzhavnogromadyans'ka komunikaciya: shlyax vid kry'zy' do vzayemodiyi [Publiccivil communication: the path from crisis to interaction]. Kiev: DP "Publishing House" Personnel" [in Ukrainian].

2. Bukhtatiy O., Radchenko O., Golovchenko G. (2009). Ukrayina medijna: na porozi informacijnoyi revolyuciyi [Ukraine media: on the threshold of the information revolution]. Kyiv: Publisher SVS Panasenko [in Ukrainian].

3. Krasin Yu. A. (2007). Sud'bi demokraty'y' v Rossy'y' [The fate of democracy in Russia]. Demokraty'ya, upravleny'e, kul'tura: problemnoe y'zmereny'e souremennoj poly'ty'ky'. Ezhegodny'k. Poly'ty'cheskaya nauka Democracy, governance, culture: the problem dimension of modern politics. Yearbook Political science, 40-60 [in Russian].

4. Rashkovskaya O. V. (2012). Gromadyans'ki iniciaty'vy' v rozvy'tku komunikacij mizh derzhavoyu ta suspil'stvom v Ukrayini [Civic Initiatives in the Development of Communications between the State and Society in Ukraine]. Zbirny'k naukovy'x pracz' NADU - Collection of scientific works of NAPA, 2, 285 [in Ukrainian].

5. Surmin Yu. P., Bakumenko V. D., Mikhnenko A. (2010). Ency'klopedy'chny'j slovny'k z derzhavnogo upravlinnya [Encyclopedic Dictionary of Public Administration]. Kyiv: NADU [in Ukrainian].

6. Mazur V. G. (2011). Komunikaciyi yak mexanizm vzayemodiyi derzhavny'x organiv vlady' ta gromads'kosti na regional'nomu rivni [Communications as a mechanism of interaction between state authorities and the public at the regional level]. Marketynh i menedzhment innovatsii Derzhavne upravlinnya: udoskonalennya ta rozvy'tok - State Administration: Improvement and Development, 8. Retrieved from http:// www.dy.nayka.com.ua/?op=1\&z=313 [in Ukrainian].

7. Gorbatenko V. P. (2004). Politologichny'j ency'klopedy'chny'j slovny'k [Political Science Encyclopedic Dictionary]. Kyiv: Geneza [in Ukrainian]. 
8. Surmin Yu. P., Bakumenko V. D., Michnenko A. (2010). Ency'klopedy'chny'j slovny'k z derzhavnogo upravlinnya [Encyclopedic Dictionary of Public Administration]. Kyiv: NADU [in Ukrainian].

9. Drachov E. V. (2014). Sutnist' ta funkciyi komunikaciyi v sy'stemi derzhavnogo upravlinnya [The essence and functions of communication in the system of public administration].
Naukovy'j visny'k Akademiyi municypal'nogo upravlinnya - Scientific Bulletin of the Academy of Municipal Administration, 3, 159-167 [in Ukrainian].

10. Romanenko E. O. (2014). Komunikaty'vna polity'ka derzhavy': teorety'kometodologichny'j analiz [Communicative Politics of the State: Theoretical and Methodological Analysis]. Kyiv: NADU [in Ukrainian]. 